\title{
Perceptual Factors Affecting the Tendency to Collaboration in SMEs: Perceived Importance of Collaboration Modes and Partners
}

\author{
Heeyong Noh ${ }^{1}$, Sungjoo Lee ${ }^{1 *}$
}

\begin{abstract}
This research aims to explore key factors of SMEs' external collaboration and to identify the factors that are perceived to affect their propensity for collaboration. In particular, we focus on two factors-internal strategic activities geared toward open innovation and external collaboration partners, both of which are essential to establishing an external collaboration. We conducted a survey of Korean SMEs regarding their collaboration project experiences, and we used logistic regression analysis to analyze the survey data. The research findings are expected to aid understanding of SMEs' complex open innovation mechanism and to have meaningful implications for the development of their collaboration models.
\end{abstract}

Keywords: SMEs, Collaboration models, Korea, Innovation

Submitted August 8th 2015 / Approved October 12th 2015

\section{Introduction}

Pavitt (1983) showed that more than half of the innovations since 1955 have come from large enterprises (LEs) with more than ten thousand employees. However, Rothwell (1984) argued that simply counting innovations does not explain the relative innovative efficiency of small and medium enterprises (SMEs) and LEs, and proposed using innovations per unit of employment or innovations per unit of output. Wyatt's (1982) analysis supports the argument that small firms' share of innovations is considerably greater than their share of $\mathrm{R} \& \mathrm{D}$ expenditures relative to LEs. It is now clear that SMEs have a strong impact on national economic growth because of their potential for innovation (Harrison and Hart, 1987; Levy and Powell, 1988). Thus, improving their competitiveness is critical to driving and developing the economy.

Among the ways to support innovation in SMEs and further enhance their competitiveness, the use of aggressive external collaboration is especially important in the context of open innovation (OI) (Lee et al., 2010; Lee et al., 2012; Westhead and Storey, 1995). Since the concept of OI was introduced, there has been extensive literature published on external collaboration (Chen et al., 2011; Enkel et al., 2009; Chiaroni, et al, 2011). For SMEs, external collaboration may be necessary in order to survive in a turbulent market environment (Lee et al., 2012). External collaboration offers a way for SMEs to extend and complement their internal resources (Lee et al., 2010) and to make up for a lack of knowledge, qualified human resources, and facilities as well as their limited market information and access (Hamdani and Wirawan, 2012; Lu and Beamish, 2001). Clearly, moving toward an external collaboration can be a logical means for SMEs to establish innovation; however, risks and costs for this movement may exist.
Various OI studies of SMEs have been conducted recently (Van de Vrande et al., 2009), and they have shown that network ties and relationships such as information sharing and resource pooling can offer technological opportunities to improve SMEs' performance (Chesbrough, 2003; Lee et al., 2010; Lipparini and Sobrero, 1994). Focusing on those advantages of external collaboration, some research has shown that both inbound and outbound strategies have positively affected SMEs' innovative performances (Bianchi et al., 2010; Parida et al., 2012). In contrast, other studies focused on the disadvantages of external collaboration, such as having to reveal proprietary information, potentially losing competitive advantage, increasing the complexity of innovation, and facing the challenges of applying the concept of OI (West and Gallagher, 2006). This double-edged sword has caused confusion regarding SMEs' use of external collaboration. Besides, SMEs' previous experiences with collaboration, which are of great importance when assessing the effectiveness of OI strategies, differ greatly. Accordingly, SMEs are likely to have different perceptions about OI. As Buytendijk (1922) said, "perception is always related to specific actions or, more precisely, perception always includes the impetus to actions" (p.24). Investigating perceptions about SMEs' external collaboration strategies will help explain their strategic behaviors toward OI. SMEs' perceptions are particularly interesting to examine, as management decisions are made mainly on the basis of insights from top managers. In spite of their significance, however, little effort has been made to deal with the issues associated with these perceptions.

To fill the research gap, therefore, this study aims to understand the determinants of collaboration tendency, focusing on two perceptual factors - the perceived importance of collaboration modes and the external collaboration partners. The former describes why and how

1 Department of Industrial Engineering, Ajou University, South Korea

*Corresponding author: sungjoo@ajou.ac.kr 
firms conduct external collaboration, and the latter indicates the type of partners involved in the collaboration. These two factors, which are regarded as core elements of OI strategies, are required to understand the complex OI process and to design and implement OI strategies (Hageddom, 2002; Keupp and Gassmann, 2009). To accomplish this, a survey of SMEs was conducted, and methods of statistical analysis such as Principal Component Analysis (PCA), correlation analysis, and logistic regression analysis were applied to the survey data. The research findings are expected to be useful for SME managers' decision-making processes regarding external collaboration and for policy makers' development and implementation of OI policies for SMEs.

The remainder of this paper is structured as follows: Section 2 reviews the literature on SMEs' external collaboration. Section 3 describes the research framework and the applied statistical analyses. Section 4 shows the analyses' results and the insights gained from the analysis. Section 5 discusses the identified problems. Finally, Section 6 addresses the implications and limitations of this research.

\section{Background}

\section{SMEs' external collaborations and the basic approach}

Although OI in SMEs has been addressed recently, the discussion on external collaboration in SMEs remains scant (Lee et al., 2010). This is because external collaborations are more easily observed in LEs, as the internal capabilities and assets of SMEs are limited, restricting their opportunities to offer something in exchange for external resources (Narula, 2004). Paradoxically, this lack of technological assets and insufficient internal resources could explain why these small companies should be eager to conduct external collaboration to enhance their internal capacity and address other insufficiencies. Moreover, due to the accelerated speed of change in the market environment (Tidd et al., 2005), SMEs' flexibility can be a very strong advantage when their aforementioned shortcomings are resolved through successful external collaboration (Levy and Powell, 1998).

However, though there is empirical evidence that open external collaborations are quite important for SMEs, challenges remain in fully realizing successful collaborations. Some studies have shown that external collaborations, such as strategic alliances or subcontracting relationships with transnational corporations, have a positive effect on SMEs' innovation performance (Kumar and Subrahmanya, 2010). Conversely, other studies have described significant barriers to improving SMEs' innovative capabilities through external collaboration (Kamalian et al., 2011; Savitskaya et al., 2010). Van de Vrande et al. (2009) showed that innovation in SMEs is becoming more open, but each open innovation practice creates its own specific problems. Therefore, while external collaboration may be advantageous to SMEs in a turbulent global market environment, firms must also recognize the barriers collaboration presents in order to implement a successful innovation strategy. For SMEs, a large investment in external collaboration can be very risky, as a firm's internal resources may be insufficient to withstand even one failed initiative. The topic of improving SMEs' innovative performance through external collaboration is extremely important and very timely, but research exploring the perceptual factors affecting collaborations is hard to find. The purpose of this study is to fill this gap by identifying the antecedents of SME collaborations in terms of their perceptions on OI strategies. To achieve the goal, we focused on the two factors-the perceived importance of collaboration modes and the types of partners; internal strategic activities, represented by the former (Keupp and Gassmann, 2009), and external collaboration partners, represented by the latter (Hageddom, 2002), are both considered significant factors in understanding complex OI processes in practice.

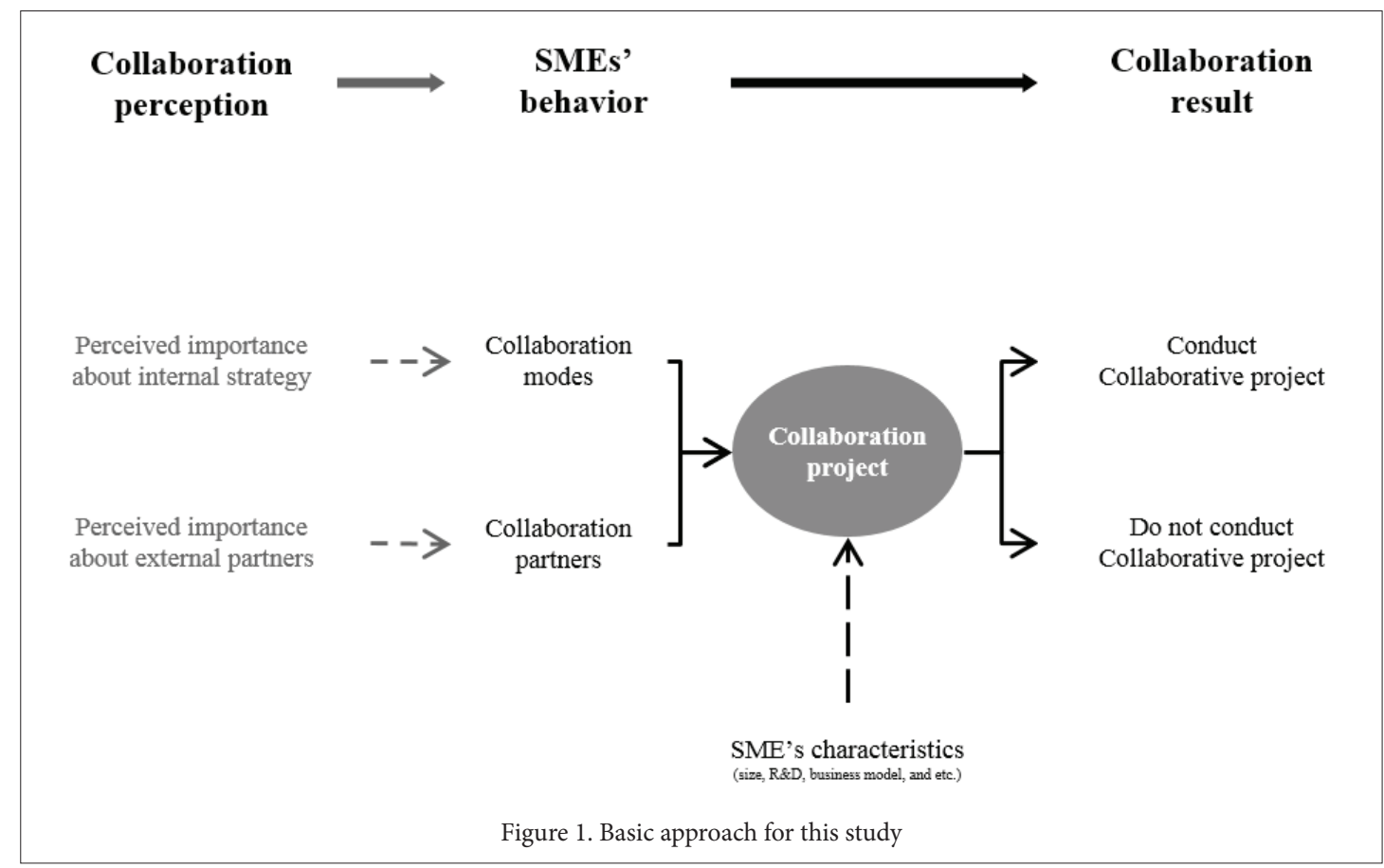

ISSN: 0718-2724. (http://jotmi.org)

Journal of Technology Management \& Innovation @ Universidad Alberto Hurtado, Facultad de Economía y Negocios. 
Thus, the basic approach to investigate the two antecedents of external collaboration is shown in Fig. 1. First of all, we assume that SMEs' perceptions about external collaboration affect their behaviors and that those behaviors influence the collaboration results. Furthermore, the perceptions about the best modes of collaboration and partner types will affect SMEs' collaborative behaviors (e.g., their efforts to form a collaboration network or their commitment to collaboration). These behaviors are expected to have a significant impact on SMEs' propensity for collaboration and on the success of their collaborations; these collaboration results will also be affected by firm-specific characteristics. Based on this approach, we firstly categorize the collaboration modes and partner types according to their perceptions of SMEs, and we then examine how these perceptions affect SMEs' tendencies for collaboration.

Firms may employ different types of collaborations to enhance performance, including interfirm collaborations such as joint ventures, research and development (R\&D) collaborations, co-productions, university-industry collaborations, and customer-industry collaborations. It is apparent that these strategic collaborations provide an opportunity for technological innovation and commercial benefit through resource pooling, technology complementing, etc. (Chesbrough, 2003; Chesbrough et al., 2006, Fitjar and Rodriguez-Pose, 2013; Kang and Park, 2012; Parmentier and Mangematin, 2014). From this perspective, Laursen and Salter (2006) showed that a firm that is too internally focused may miss profitable opportunities because it lacks resources that can only be obtained outside the firm. Likewise, a number of researchers have focused on the relationship between collaboration and its outcomes. The relationship between technology exploration-an inbound collaboration also known as the external technology acquisition (ETA) process-and innovative performance has been widely studied (Kurokawa, 1997; Sisodiya et al., 2013), and Procter \& Gamble's case is one of the most well-known examples in the field of business management (Chesbrough et al., 2006). Research has also been conducted on the benefits of technology exploitation, a form of outbound collaboration also known as the external technology exploitation (ETE) process (Arora and Fosfuri, 2003; Athreye and Cantwell, 2007; Mendi, 2007).

However, is it possible to say that every type of external collaboration boosts the technological or financial performance of a firm in the same way? Some researchers have warned that building external collaborations without careful consideration of the risks may not increase a firm's internal capabilities and may even negatively impact its performance (Fey and Birkinshaw, 2005; Kafouros and Forsans, 2011). For firms undertaking inbound collaboration, factors such as their absorption capacity, "Not invented here" (NIH) syndrome, and asymmetric information about the technology market can be barriers to achieving innovative performance or enhancing the firm's internal capabilities (Kani and Motohashi, 2012; Savitskaya et al., 2010; West and Gallagher, 2006). Similarly, concerns such as rent dissipation, "Not sold here" (NSH) syndrome, the complexity of intellectual property rights (IPR), and fear of disclosing proprietary information can make a firm hesitant about engaging in outbound collaboration (Kani and Motohashi, 2012; Savitskaya et al., 2010; West and Gallagher,
2006). Interestingly, these factors are greatly associated with perceptions about external collaboration; thus, considering such perceptual factors is necessary to identify why some SMEs seek to conduct external collaboration while others do not.

\section{Collaboration strategies and questions for exploration research}

In the previous section, the basic approach of this study was described, including two significant factors: collaboration modes and collaborative partners. As each factor has varied types and different characteristics, we should figure out how the factors are explained in the existing studies. To achieve this, effectiveness and efficiency are useful concepts for understanding why and how firms conduct external collaboration; effectiveness is often said to mean "doing the right thing" to contrast with efficiency, or "doing things right." Based on the concepts of effectiveness and efficiency, we can raise a set of questions regarding whether perceptual factors affect SMEs' tendency to collaborate. Three kinds of questions are considered here: 1) perception context, 2) collaboration modes, and 3) collaboration partners.

First, as the aforementioned basic approach of this study assumes that SMEs' perceptions about external collaboration affect their behaviors and that these behaviors influence collaboration results, there should be significant causal relationships between SMEs' perceptions regarding the importance of external collaboration and their actual propensity to conduct external collaboration when the basic approach is properly constructed.

Q1. Does the perceived importance of external collaboration have a significant impact on SMEs' propensity for conducting external collaboration?

Secondly, collaboration modes are important in describing collaboration strategies. SMEs can have many motives for conducting collaborations with other organizations. In many cases, a firm may want to seek the opportunity to resolve its managerial problems or to otherwise benefit from collaborations. In this context, Cho et al. (2015) showed that there are two major drivers of SMEs' technology opportunity discovery: 1) opportunity discovery from the market and 2) opportunity creation by technology. According to the concept of effectiveness, these market and technology opportunities would have different levels of effectiveness for SMEs. However, opportunity discovery from the market might be more effective than opportunity creation by technology. This is both because SMEs typically lack the resources (Hamdani and Wirawan, 2012; Lu and Beamish, 2001) to develop technology that can create a new opportunity and because opportunity discovery from market can be less risky than developing a new technology with $\mathrm{R} \& \mathrm{D}$ investment.

Q2a. For SMEs' collaboration propensity, does the perceived importance of discovering opportunity from the market have a stronger impact than the perceived importance of creating opportunity through technology?

Hollanders and Celikel-Esser (2007) found that innovation efficiency is improved when more innovation outputs are generated with the same amount of innovation inputs or when fewer innovation inputs 
are needed for the same amount of innovation outputs. In the collaboration context, a firm might choose an inflow strategy or an outflow strategy based on which offers a more efficient method of collaboration. For example, a pharmaceutical SME might want to exploit a new technology that it developed. Anand and Khanna (2000) showed that there is a relatively high licensing propensity to earn extra rent in the pharmaceutical industry, compared with other industries. On the other hand, some micro-organizations and start-ups may want to focus on user-involved collaboration. Living Labs is one of the most popular user-involved external collaborations for SMEs that typically have problems acquiring venture capital to ensure reliable market evaluation (Eriksson et al., 2005; Wadhwa, 2012). In other cases, an alliance of SMEs may be formed to coproduce a product because the cost of acquiring manufacturing facilities would be too high for a single SME to manage alone. In summary, firms' internal strategic activities represent their needs and desires, and significant relationships between strategies and outcomes exist (Mosakowski, 1993). Although internal strategic activities vary according to the specific desires or demands of each firm, inbound strategies for external collaboration are much more common than outbound activities. Outbound activities present a higher level of managerial challenge due to the imperfect and asymmetric information structure of the technology market (Kani and Motohashi, 2012) and to the lack of systematic internal processes to facilitate outward exploitation. SMEs also tend to struggle with external collaboration by acquiring valuable resources from external environments rather than by utilizing an outbound strategy (Parida et al., 2012). Similarly, the perceived importance of an inflow strategy might be a more significant factor than the perceived importance of an outflow strategy in explaining whether SMEs conduct collaboration.

Q2b. Does the perceived importance of inflow strategy have a stronger impact than the perceived importance of outflow strategy in explaining SMEs' collaboration propensity?

Thirdly, collaboration partnership is another important factor when SMEs are conducting external collaboration. SMEs' relationships with stakeholders can be valuable resources in the context of OI. Researchers have identified several technical partners that can be used to examine the relationships between collaborative partners and innovation (Bougrain and Haudeville, 2002; Lee et al., 2010). Furthermore, most innovative companies have strong cooperative ties with external stakeholders, and their important partners are primarily value-chain stakeholders, such as clients, customers, and suppliers (Doloreux and Mattson, 2008). Tomlinson and Fai (2013) also showed that the supply chain positively affects a firm's innovation. Thus, collaboration partners are selected based on which collaboration opportunity is employed and how it is employed. Collaboration modes are described by the concepts of effectiveness and efficiency, which denote collaboration opportunities and collaboration application methods, respectively, in this study. Therefore, collaboration partners can be grouped in accordance with collaboration modes. There are two major drivers of SMEs' technology opportunity discoveries (Cho et al., 2015). R\&D-related organizations and public institutions might be proper collaboration partners when SMEs choose the opportunity creation by technology strategy. On the other hand, market-related stakeholders can be useful collaboration partners for the discovering opportunity from market strategy. In addition, Husted and Allen (2007) showed that there are two types of market-related activities to achieve corporate social strategy: value chain activities and non-value chain activities. Although value chain activities have long been a source of focus, non-value chain related activities have only been considered critical in recent strategic management approaches. In other words, market opportunity partners should be grouped into value chain stakeholders who are directly related to the market competition and non-value chain stakeholders who are indirectly related to the market competition. In question $2 \mathrm{a}$, we supposed that opportunity discovering from the market would be more effective than opportunity creation by technology. Likewise, market stakeholders may be more effective than R\&D stakeholders at explaining SMEs' propensity for collaboration.

Q3a. Does the perceived importance of market stakeholders have a stronger impact than the perceived importance of R\&D stakeholders on SMEs' collaboration propensity?

Under the context of efficiency, an external organization can help an SME to improve the efficiency of its resource acquisition or resource allocation capabilities. Robson and Bennett (2000) noted that external business advice has a positive effect on SMEs' performance. In particular, private sector sources such as lawyers, suppliers, customers, and friends or relatives dominated the main positive relationships in business advice and SME performance. Wren and Storey (2002) also demonstrated that the use of outside consultants can overcome SMEs' substantial market failure. Therefore, SMEs' business and support services might work positively to conduct external collaboration.

Q3b. Does the perceived importance of business services, such as accounts, legal support, and consultants have a significant impact on describing SMEs' propensity for collaboration?

\section{Research framework}

\section{Research process}

This study aims to explore the practical antecedents of SMEs' successful collaborations by looking at the perceived importance of collaboration modes and partners from the SMEs' perspectives. Fig. 2 shows the research process. A survey was carried out to investigate the current state of SMEs' OI activities. In the survey, questions about broad types of collaboration modes and partners were asked in order to derive the practical determinants of SMEs' external collaborations. In the second stage of the process, Varimax-rotated PCA was conducted to typify patterns of collaboration modes and partners. Following that, correlation analysis was used to develop models of external collaboration. Finally, in the third stage, the perceptual factors affecting the tendency toward collaboration were explored using logistic regression analysis. 


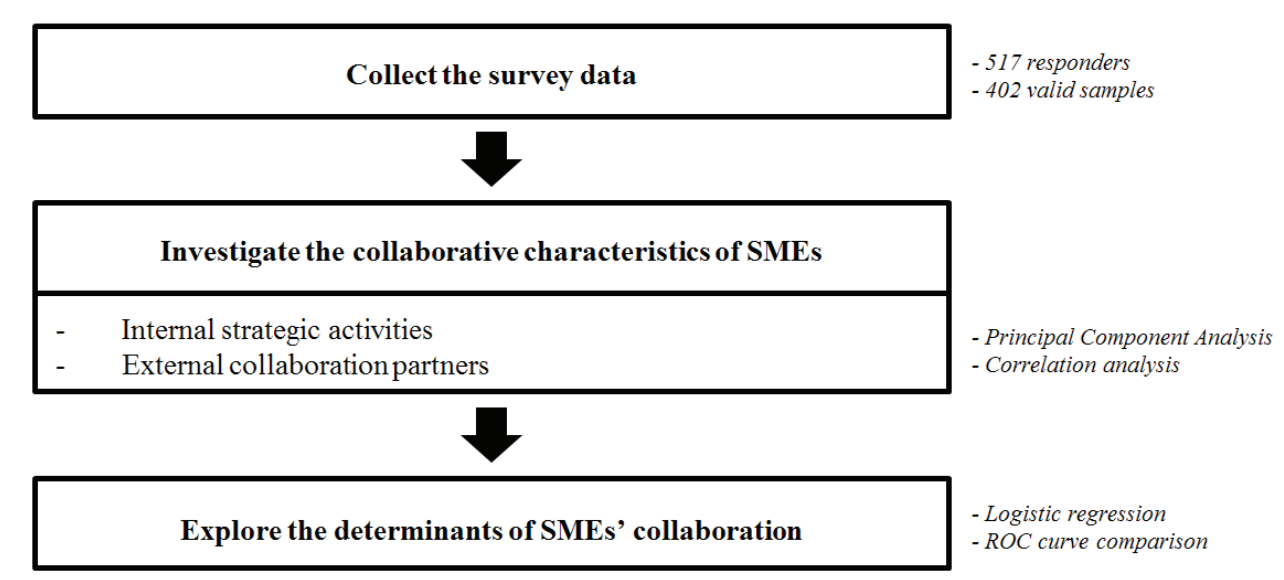

Figure 2. Overall research process

\section{Detailed procedures}

Collect data. To address the questions related to Korean SMEs, it was necessary to first investigate their current state. To examine the current state, a survey was designed to gather information on firms' business models, collaborative activities, and other basic business information. The survey was conducted from September 28 to October 27, 2011. A total of 517 SMEs responded, and 402 remained after eliminating invalid data sets. For the basic survey design, three categories were borrowed from Gassmann (2006), who claimed that OI is more prevalent in industries characterized by globalization, technology intensity, technology fusion, new business models and knowledge leveraging. Thus, the survey contained three parts: 1) general characteristics, in which SMEs answered questions about their firm size, R\&D intensity, and business model; 2) the perceived importance of various collaboration modes and partners, which was measured using a 5-point Likert scale from 1 ("very low importance") to 5 ("very high importance"); and 3) experiences with collaboration projects. In addition, we referenced the work by Rosenfeld (1996), Xu et al., (2005), and Van de Vrande et al., (2009) to define the possible collaboration modes and the work by Lee et al. (2010) and Cho et al. (2015) to define the potential partners. As each work described diverse type of collaboration modes and partners, we can ask potential modes and partners for interfirm collaboration as many as possible.

Investigate the collaborative characteristics of SMEs. Logistic regression analysis was the primary statistical method used in this study. A risk associated with logistic regression is over-fitting, as multidimensional factors such as internal strategic activities and external collaboration partners are included in the analysis. Model fitting can cause serious problems with multidimensional data in regression analysis, and minimizing the number of explanatory variables is a good rule of thumb to avoid over-fitting. PCA was used to not only reduce the dimensions of the internal and external factors but also to categorize the types of collaboration modes and partners. In PCA, axes are explored sequentially and can represent a variation of scattered data by considering the eigenvectors of the correlation matrix for observations. Through this process, information on variables can be condensed into derived axes (reducing dimensions), and an interpretation on each axis can be carried out by considering higher loading values (labeling is addressed in the results section). The second consideration when working with the data in this study was multicollinearity, which occurs when there is a strong correlation among the explanatory variables in a regression model. It was important to resolve this issue because there is an unavoidable correlation between the collaboration modes and the partners. Correlation analysis was conducted, and, based on the relatively high correlations that were observed between factors, the research models were separated into two - one for collaboration modes and one for collaboration partners.

Explore the determinants of SMEs' collaboration. Logistic regression analysis was selected as the main statistical method, first, because the predictor variable is categorical, and second, because cause-effect analysis is required to investigate the determinants of SMEs' collaboration results. The estimated coefficient values of the logistic regression analysis could explain the determinants of each research model. While conducting logistic regression analysis, Receiver operating characteristics (ROC) curves were used. In signal detection theory, an ROC curve describes the performance of a classifier system by plotting the cumulative distribution function for the detection probability. Therefore, we can identify the high performance of a logistic regression analysis when its area under the curve (AUC) is large. In this research, the influences of various factors were examined by comparing each AUC in the research model; the method suggested by DeLong et al. (1998) was applied to compare AUCs. 


\begin{tabular}{|c|c|c|c|}
\hline & Category & Variables & Description \\
\hline \multirow{8}{*}{$\begin{array}{c}\text { Control } \\
\text { variables }\end{array}$} & \multirow[b]{5}{*}{ R\&D activities } & \multirow[t]{2}{*}{$\begin{array}{l}\text { Firm size } \\
\text { (number of employees) }\end{array}$} & $\begin{array}{l}\text { 1. Small sized SME: less than } 50 \text { employees } \\
\text { 2. Medium sized SME: Between } 50 \text { and } 250 \text { employees } \\
\text { 3. Large sized SME: more than } 250 \text { employees }\end{array}$ \\
\hline & & & \\
\hline & & Industry sector & $\begin{array}{l}\text { 1. Manufacturing } \\
\text { 2. Transportation } \\
\text { 3. Professional, scientific, and technical activities }\end{array}$ \\
\hline & & $\mathrm{R} \& \mathrm{D}$ intensity & $\begin{array}{l}\text { 1. No R\&D investment: } 0 \text { percent } \\
\text { 2. Small investment on R\&D: } 1 \text { percent to } 5 \text { percent } \\
\text { 3. Medium investment on R\&D: } 6 \text { percent to } 10 \text { percent } \\
\text { 4. Large investment on R\&D: more than } 10 \text { percent }\end{array}$ \\
\hline & & R\&D fulfillment type & $\begin{array}{l}\text { 1. Conducting R\&D continuously } \\
\text { 2. Conducting R\&D process when R\&D is needed } \\
\text { 3. Little R\&D, but incrementally improving product/process } \\
\text { 4. Affected by } R \& D \text { of external organizations }\end{array}$ \\
\hline & \multirow{3}{*}{ Business model } & Target market & $\begin{array}{l}\text { 1. Specific area in domestic market } \\
\text { 2. Overall domestic market } \\
\text { 3. Developed countries (USA, Japan, Europe, etc.) } \\
\text { 4. Developing countries (China, India, Russia, South-East Asia, etc.) }\end{array}$ \\
\hline & & Main customer type & $\begin{array}{l}\text { 1. Common market transaction } \\
\text { 2. Long-term subcontract } \\
\text { 3. A specific individual or a public sector customer }\end{array}$ \\
\hline & & Competitive advantage & $\begin{array}{l}\text { 1. Differentiation strategy } \\
\text { 2. Cost-leadership strategy } \\
\text { 3. Focus strategy }\end{array}$ \\
\hline \multirow{2}{*}{$\begin{array}{l}\text { Exploratory } \\
\text { variables }\end{array}$} & $\begin{array}{l}\text { Perceived } \\
\text { Importance of } \\
\text { collaboration modes }\end{array}$ & \multicolumn{2}{|c|}{$\begin{array}{l}\text { Involvement of users and customers; Using external experts; Using collective intelligence; Crowd sourcing } \\
\text { or solution contest; Using unofficial networks of a firm; Using official networks of a firm; Technology } \\
\text { buying; Mergers \& Acquisitions (M\&A); Joint R\&D; R\&D consortium; Co-marketing and Co-branding; } \\
\text { Coproduction; Joint purchasing; R\&D outsourcing; Outsourcing except R\&D; Investment on external } \\
\text { organization; Technology selling; Foundation of venture business; Joint venturing; Open platform }\end{array}$} \\
\hline & $\begin{array}{l}\text { Perceived } \\
\text { importance of } \\
\text { collaboration } \\
\text { partners }\end{array}$ & \multicolumn{2}{|c|}{$\begin{array}{l}\text { Clients and customers; Suppliers; Competitors; Affiliates; Complementary companies; IT support business } \\
\text { (S/W, IT system); Business services (Accounting, consulting); Governmental funded research centers; Non- } \\
\text { governmental funded research centers; Universities; Non-profit organizations }\end{array}$} \\
\hline
\end{tabular}

Table 1. Control and exploratory variables

The variables that were measured were divided into three types. First, experience with collaboration projects was used as a predictor variable. To decide this, respondents were asked, "Is there a new service/product development project that has achieved innovative performance through external collaboration in the last three years?" If a firm answered affirmatively, it was classified as a successful case. Failed cases were those that had engaged in an external collaboration but had unsatisfactory outcomes. Both are regarded as firms with collaboration experiences. The third category included firms that had not collaborated with an external partner in the past three years. This classification was used to explore the determinants of external collaboration propensity. Secondly, the general characteristics of the business were used as a control variable for investigating SMEs' external collaborations. A total of seven variables were included. The third type of variable is an explanatory variable. Most existing studies of
SMEs' external collaborations and network ties have not considered the various aspects of cooperation and innovation, as Tomlinson and Fai (2013) argued. The explanatory variables in this study were the perceived importance scores, measured using a 5-point Likert scale, of the broad types of internal strategic activities and external collaboration partners. Details of the variables are provided in Table 1.

\section{Results}

\section{Perceived importance of collaboration modes and partners}

Of the 402 firms that are represented in the analysis, 190 had engaged in external collaboration in the past three years; the rest had not. As a result, the responses from the 402 participants were used to examine propensity to conduct external collaboration. The first step of the research process was to reduce the dimensions of the importance ratings 
for 20 variables related to the perceived importance of collaboration modes and for 11 variables concerning the perceived importance of collaboration partners. PCA was applied to identify the underlying components of both internal and external factors.

The PCA results of the collaboration modes are shown in Table 2. The total cumulative variance of the four principal components (PCs) is 78 percent, meaning that these four factors represent 78 percent of the variance in the 20 original variables. Through the results' factor loading values, we can identify each PC as having its own meaning. Interestingly, PCA results can be clearly separated into collaboration modes, which were described in previous studies under the concepts of effectiveness and efficiency. To interpret the PCA results, relatively high loading values are considered to label each PC. For internal collaboration modes, a loading value of at least 0.6 is relatively high. Consequently, PC1 and PC2 can be explained by effectiveness, and PC3 and PC4 can be described by efficiency. For PC1, the discovering market opportunity mode is proper, as it has relatively high loading values for idea-creation activities, including the involvement of users and customers, the use of external experts, and the use of collective intelligence. Market opportunities—such as market needs, solutions, novel ideas for new products or processes, and valuable information on formal or informal networks - can be discovered through those idea-creation activities. The second PC can be labeled as the collaborative R\&D mode. A firm with high $\mathrm{PC} 2$ scores is likely to have fewer internal resources, making it hard for a firm to conduct R\&D (which requires huge investments and risks). The third component is the utilizing internal resources mode. Firms with a relatively high PC3 score may have a technological advantage and may be able to increase their competitiveness through outbound activities. The last component, PC4, describes firms that are very different from those with high PC2 scores. These firms, representing the acquiring strategic resources mode, have a large internal capacity, which allows them to pursue activities such as technology purchases, mergers \& acquisitions, coproduction, and joint purchasing. These labels represent each mode of internal collaboration, and thus, Cronbach's alpha is employed to identify the internal consistency of each PC. The derived values of Cronbach's alpha are all plausible $(\geq 0.7)$.

\begin{tabular}{|c|c|c|c|c|}
\hline Variables & PC1 & PC2 & PC3 & PC4 \\
\hline Involvement of users and customers & 0.72 & 0.22 & 0.19 & 0.19 \\
\hline Using external experts & 0.70 & 0.48 & 0.22 & 0.18 \\
\hline Using collective intelligence & 0.69 & 0.43 & 0.25 & 0.26 \\
\hline Crowd sourcing or solution contest & 0.64 & 0.35 & 0.21 & 0.40 \\
\hline Using unofficial networks of a firm & 0.82 & 0.16 & 0.15 & 0.25 \\
\hline Using official networks of a firm & 0.73 & 0.39 & 0.21 & 0.24 \\
\hline Technology buying & 0.59 & 0.14 & 0.27 & 0.61 \\
\hline Mergers \& Acquisitions (M\&A) & 0.42 & 0.20 & 0.20 & 0.71 \\
\hline Joint R\&D & 0.50 & 0.65 & 0.23 & 0.31 \\
\hline $\mathrm{R} \& \mathrm{D}$ consortium & 0.49 & 0.69 & 0.24 & 0.29 \\
\hline Co-marketing and Co-branding & 0.38 & 0.50 & 0.32 & 0.49 \\
\hline Coproduction & 0.25 & 0.49 & 0.22 & 0.67 \\
\hline Joint purchasing & 0.21 & 0.41 & 0.24 & 0.75 \\
\hline$R \& D$ outsourcing & 0.34 & 0.75 & 0.27 & 0.32 \\
\hline Outsourcing except R\&D & 0.36 & 0.67 & 0.31 & 0.36 \\
\hline Investment on external organization & 0.37 & 0.48 & 0.33 & 0.47 \\
\hline Technology selling & 0.22 & 0.06 & 0.79 & 0.16 \\
\hline Foundation of venture business & 0.16 & 0.22 & 0.85 & 0.16 \\
\hline Joint venturing & 0.12 & 0.30 & 0.84 & 0.18 \\
\hline Open platform & 0.24 & 0.19 & 0.82 & 0.19 \\
\hline Variance ( percent) & 24.33 & 18.89 & 18.46 & 16.51 \\
\hline Cumulative variance ( percent) & 24.33 & 43.22 & 61.68 & 78.19 \\
\hline Cronbach's alpha for high loadings & 0.929 & 0.940 & 0.906 & 0.895 \\
\hline Types of internal collaboration modes & $\begin{array}{c}\text { Discovering } \\
\text { market opportunity }\end{array}$ & Collaborative R\&D & $\begin{array}{l}\text { Utilizing internal } \\
\text { resources }\end{array}$ & $\begin{array}{l}\text { Acquiring strategic } \\
\text { resources }\end{array}$ \\
\hline
\end{tabular}

Table 2. PCA results of internal collaboration modes 
The PCA results of external collaboration partners are shown in Table 3 . The new, derived factors are good substitutes for the eleven original variables, as the total variation explained by the four PCs is 86 percent. Like the PCA labeling results for the collaboration modes, the PCA results for the collaboration partners follow the concepts of effectiveness and efficiency. To interpret the PCs regarding collaboration partners, the loading values of at least 0.55 can be considered relatively high. As a result, $\mathrm{PC} 1, \mathrm{PC} 2$, and $\mathrm{PC} 3$ are under the effectiveness concept, and PC4 is under the efficiency concept. PC1 can also be called emphasis on R\&D institutions. Variables that have high factor loadings in this segment are directly engaged in technology development at academic or practical research institutions. The second PC, described as emphasis on market-direct stakeholders, has relatively high factor loading values, not only for stakeholders in the conventional supply chain but also for competitors. Most previous studies on the relationship between SMEs' collaboration and performance have primarily focused on ties to the cooperative supply chain and to the competition, both of which are very important, based on their direct relationship in a focal market. On the other hand, affiliates and complementary companies have high loading values in the third PC, emphasis on market-indirect stakeholders. These kinds of stakeholders also affect a firm's performance, but they are not directly engaged in the focal market. Finally, PC4 is closely related to IT and business support. Thong (2001) showed that critical benefits-such as increased sales, improved profitability, increased productivity, improved decision making, and secured competitiveness-can be achieved through information system implementation. Accounting and consulting can also improve SMEs' managerial performance. Therefore, we can describe PC4 as emphasis on solution partners, as these support stakeholders can help SMEs by providing professional solutions. In addition, the alpha values for all the PCs are more than 0.8 , indicating that the labeling is proper.

\begin{tabular}{|c|c|c|c|c|}
\hline Variables & PC1 & PC2 & PC3 & PC4 \\
\hline Clients and customers & 0.25 & 0.87 & 0.05 & 0.22 \\
\hline Suppliers & 0.18 & 0.87 & 0.27 & 0.18 \\
\hline Competitors & 0.27 & 0.77 & 0.38 & 0.14 \\
\hline Affiliates & 0.37 & 0.25 & 0.80 & 0.21 \\
\hline Complementary companies & 0.23 & 0.52 & 0.63 & 0.35 \\
\hline IT support business (S/W, IT system) & 0.40 & 0.35 & 0.29 & 0.73 \\
\hline Business services (Accounting, consulting) & 0.46 & 0.39 & 0.37 & 0.56 \\
\hline Governmental funded research centers & 0.79 & 0.20 & 0.16 & 0.41 \\
\hline Non-governmental funded research centers & 0.86 & 0.29 & 0.17 & 0.22 \\
\hline Universities & 0.88 & 0.23 & 0.18 & 0.18 \\
\hline Non-profit organizations & 0.80 & 0.17 & 0.40 & 0.09 \\
\hline Variance ( percent) & 31.76 & 26.49 & 15.62 & 12.50 \\
\hline Cumulative variance ( percent) & 31.76 & 58.25 & 73.87 & 86.37 \\
\hline Cronbach's alpha for high loadings & 0.938 & 0.906 & 0.827 & 0.856 \\
\hline Types of external collaborative partners & R\&D institutions & $\begin{array}{l}\text { Market-direct } \\
\text { stakeholders }\end{array}$ & $\begin{array}{l}\text { Market-indirect } \\
\text { stakeholders }\end{array}$ & Solution partners \\
\hline
\end{tabular}

Table 3. PCA results for external collaboration partners

\section{Propensity to conduct external collaboration}

After the PCA, a correlation analysis was conducted to avoid multicollinearity before applying PCs to a logistic regression analysis. Relatively high correlations were observed between discovering market opportunity strategy and emphasis on market-direct stakeholders (0.51, $\mathrm{p}=0.00$ ), between collaborative R\&D strategy and emphasis on R\&D institutions $(0.35, \mathrm{p}=0.00)$, and between utilizing internal resources strategy and emphasis on solution partners $(0.43, \mathrm{p}=0.00)$. Based on this finding, the research model cannot consider internal collaboration modes and external collaboration partners simultaneously.
According to the results of the PCA and correlation analysis, a logistic regression analysis was separately applied to three research models (see Table 4). The results show that SMEs tend to conduct external collaborations when they are focused on discovering market opportunities, supplementing insufficient internal capabilities, and acquiring technological and commercial resources. Moreover, network ties with external R\&D institutions and stakeholders who are related directly to the market increase the probability of collaboration. Network ties with stakeholders related indirectly to the market increase the probability of collaboration significantly, at the significance level of 0.1 . 
Propensity to conduct external collaboration

(Case of conducted external collaboration $=1$, Case of no experience conducting external collaboration $=0$ )

\begin{tabular}{|c|c|c|c|c|c|c|c|c|c|c|c|c|}
\hline \multirow{2}{*}{$\begin{array}{c}\text { Models } \\
\text { Variables }\end{array}$} & \multicolumn{4}{|c|}{ Research model $1^{\star * *}(\mathrm{p}=0.00)$} & \multicolumn{4}{|c|}{ Research model $2^{* * *}(\mathrm{p}=0.00)$} & \multicolumn{4}{|c|}{ Research model $3^{* *}(\mathrm{p}=0.00)$} \\
\hline & Estimate & Wald & $\begin{array}{l}\text { Odds } \\
\text { ratio }\end{array}$ & p-value & Estimate & Wald & $\begin{array}{l}\text { Odds } \\
\text { ratio }\end{array}$ & p-value & Estimate & Wald & $\begin{array}{l}\text { Odds } \\
\text { ratio }\end{array}$ & p-value \\
\hline \multicolumn{13}{|l|}{ Control variables } \\
\hline Firm size & & 1.72 & & 0.42 & & 1.85 & & 0.40 & & 2.02 & & 0.36 \\
\hline R\&D intensity & & $15.90^{* * *}$ & & 0.00 & & $8.51^{\star *}$ & & 0.04 & & $7.87^{\star *}$ & & 0.05 \\
\hline $\mathrm{R} \& \mathrm{D}$ fulfillment type & & $32.00^{\star * *}$ & & 0.00 & & $23.73^{\star * *}$ & & 0.00 & & $18.08^{\star * *}$ & & 0.00 \\
\hline Industry sector & & 3.33 & & 0.19 & & 1.41 & & 0.49 & & 1.82 & & 0.40 \\
\hline Target market & & $9.50^{\star *}$ & & 0.02 & & $8.87^{\star *}$ & & 0.03 & & $9.72^{\star *}$ & & 0.02 \\
\hline Main customer type & & 3.69 & & 0.16 & & 1.80 & & 0.41 & & 1.84 & & 0.40 \\
\hline Competitiveness advantage & & 1.20 & & 0.55 & & 0.80 & & 0.67 & & 0.66 & & 0.72 \\
\hline \multicolumn{13}{|l|}{ Internal collaboration modes } \\
\hline Discovering market opportunity & & & & & $0.61^{\star * *}$ & 18.46 & 1.83 & 0.00 & & & & \\
\hline Collaborative R\&D & & & & & $0.37^{\star \star \star}$ & 7.98 & 1.45 & 0.01 & & & & \\
\hline Utilizing internal resources & & & & & -0.14 & 1.03 & 0.87 & 0.31 & & & & \\
\hline Acquiring strategic resources & & & & & $0.33^{\star *}$ & 5.75 & 1.39 & 0.02 & & & & \\
\hline \multicolumn{13}{|l|}{ External collaboration partners } \\
\hline $\mathrm{R} \& \mathrm{D}$ institutions & & & & & & & & & $0.80^{* * *}$ & 26.97 & 2.23 & 0.00 \\
\hline Market-direct stakeholders & & & & & & & & & $0.60^{* * *}$ & 17.62 & 1.82 & 0.00 \\
\hline Market-indirect stakeholders & & & & & & & & & $0.23^{*}$ & 2.87 & 1.25 & 0.09 \\
\hline Solution partners & & & & & & & & & -0.08 & 0.28 & 0.93 & 0.60 \\
\hline Constant & $2.88^{\star \star}$ & 3.79 & 17.838 & 0.05 & 2.40 & 2.30 & 11.06 & 0.13 & 2.13 & 1.97 & 8.46 & 0.16 \\
\hline -2 log likelihood & & & & 426.89 & & & & 395.95 & & & & 382.45 \\
\hline $\begin{array}{c}\text { Model } \\
\text { Summary }\end{array}$ & & & & 0.28 & & & & 0.33 & & & & 0.35 \\
\hline Nagelkerke's R2 & & & & 0.37 & & & & 0.44 & & & & 0.47 \\
\hline $\begin{aligned} * * * & \text { p-value }<0.01 \\
{ }^{*}: & \text { p-value }<0.05 \\
* & \text { p-value }<0.1\end{aligned}$ & & & & & & & & & & & & \\
\hline
\end{tabular}

Table 4. Logistic regression results

\section{Findings and implications}

\section{Main findings}

From the results of the logistic regression analysis, we could observe some statistically significant perceptual factors affecting the tendency of collaboration in SMEs. Nine antecedents influence whether an SME enters into collaboration, as shown in Table 5. The existence of significant perceptual factors means that Q1 is revealed as positive.
Moreover, every significant perception has a positive relationship with an SME's propensity of conducting external collaboration. This indicates that the collaboration probability of SMEs would be high when managers' perceived importance of collaboration modes or partners is high. Although little effort has been made to deal with the issues associated with perceptions, this study shows that managerial behavior can be read by managerial perceptions. Thus, this perceptual approach on external collaboration can contribute to extending further managerial studies. 


\begin{tabular}{|c|c|c|}
\hline $\begin{array}{l}\text { Collaboration results } \\
\text { (Predictor variables) }\end{array}$ & $\begin{array}{c}\text { General factors } \\
\text { (Control variables) }\end{array}$ & $\begin{array}{l}\text { Perceptions and behaviors } \\
\text { (Exploratory variables) }\end{array}$ \\
\hline \multirow{2}{*}{$\begin{array}{l}\text { Propensity to conduct external } \\
\text { collaboration }\end{array}$} & \multirow{2}{*}{$\begin{array}{l}\text { R\&D intensity } \\
\text { R\&D fulfillment type } \\
\text { Target market }\end{array}$} & $\begin{array}{l}\text { Discovering market opportunity strategy } \\
\text { Collaborative R\&D strategy } \\
\text { Acquiring strategic resources }\end{array}$ \\
\hline & & $\begin{array}{l}\text { Emphasis on R\&D institutions } \\
\text { Emphasis on market-direct stakeholders } \\
\text { Emphasis on market-indirect stakeholders }\end{array}$ \\
\hline
\end{tabular}

Table 5. Antecedents of SMEs' external collaboration

For the questions on collaboration modes, factors about both opportunity discovery from the market and opportunity creation by technolo$g y$ are statistically significant. However, the odds ratio of discovering market opportunity is higher than the odds ratio of collaborative Re $D$ $(1.83>1.45)$. This means that Q2a is positive. Similarly, although the perceived importance of utilizing internal resources (outflow) is not statistically significant, the perceived importance of acquiring strategic resources (inflow) is statistically significant and positive. So, Q2b is also positive.

The results of the causal-effect analysis on collaboration partners (Research model 3) are also insightful. Three perceptual factors-R\&D institutions, market-direct stakeholders, and market-indirect stakeholders-are statistically significant and positive. This means that perceptions of collaboration partners are important for understanding SMEs' collaboration propensity. However, Q3a and Q3b are negative. Q3a is similar to Q2a, which describes that the perceived importance of market stakeholders might be more effective compared to the perceived importance of R\&D stakeholders. Market opportunity is more effective than technology opportunity in collaboration modes (Q2a); nevertheless, the odds ratio of R\&D institutions (2.23) is much higher than the odds ratios of both market-direct (1.82) and market-indirect stakeholders (1.25). Why are R\&D institutions as collaboration partners more effective than market stakeholders, while opportunity creation by technology is less effective than opportunity discovery from the market? Even if it is not easy to explain that perceived importance of R\&D institutions is most effective for an SME's collaboration propensity in this research, this result might be affected by different degrees of public confidence. R\&D institutions commonly consist of experts or professionals who have a high degree of public confidence. On the other hand, market stakeholders, such as customers or private firms, have relatively low public confidence compared to the R\&D institutions. In addition, a technology transfer from $R \& D$ institutes can be a chance to be supported financially by government agencies. Furthermore, collaborating with R\&D institutions is less risky, as they are not considered potential market competitors in many cases. For these reasons, $R \& D$ institutes can be more effective than market stakeholders in describing whether SMEs conduct external collaboration. Finally, the perceived importance of solution partners is not statistically significant, so Q3b is negative. Insufficient finance of SMEs might be a reason that perceived importance of solution partners cannot work significantly.
Interestingly, PCA results can be clearly interpreted with collaboration modes, which were described in previous studies under the concept of effectiveness and efficiency. PC1 and PC2 can be explained within the effectiveness, and PC3 and PC4 can be described within the efficiency. Like the PCA labeling results of collaboration modes, the PCA results of collaboration partners also follow the concept of effectiveness and efficiency. In this analysis, PC1, PC2, and PC3 follow the effectiveness concept, and the last PC is under the efficiency concept.

\section{Discussions}

In addition to the main findings, there are several issues to be discussed based on the results. First of all, a broad range of internal collaboration modes and external collaboration partners for SMEs could be grouped into four types. In short, we could identify that there are four major approaches to external collaborations in SMEs, which include discovering market opportunity, collaborative R\&D, utilizing internal resources, and acquiring strategic resources. Similarly, there are four types of partnering for collaboration in SMEs, focusing on R\&D institutions, market-direct stakeholders, market-indirect stakeholders, and solution partners.

Second, four significant relationships between collaboration modes and partners were observed during the correlation analysis. Especially for the three pairs- "discovering market opportunity strategy and emphasis on market-direct stakeholders," "collaborative R\&D strategy and emphasis on R\&D institutions," and "utilizing internal resources strategy and emphasis on solution partners" - we could observe statistically significant correlations. Regarding the first one, we could say that SMEs tend to focus on market-directed stakeholders (e.g., clients and customers, suppliers) when they want to discover market opportunities (e.g., using collective intelligence, crowd sourcing or solution contests). As to the second one, SMEs try to accomplish R\&D by connecting outside R\&D institutions (e.g., research centers, universities) when they want to focus on collaborative R\&D, which might be quite natural. $R \& D$ often requires a huge amount of resources with high risks, and so SMEs lacking internal resources are likely to collaborate with other research-oriented organizations. Moreover, as to the final one, SMEs having technological advantages or abundant internal resources may want to improve their business efficiency and organizational systems by collaborating with solution partners such as IT/business support service firms. 


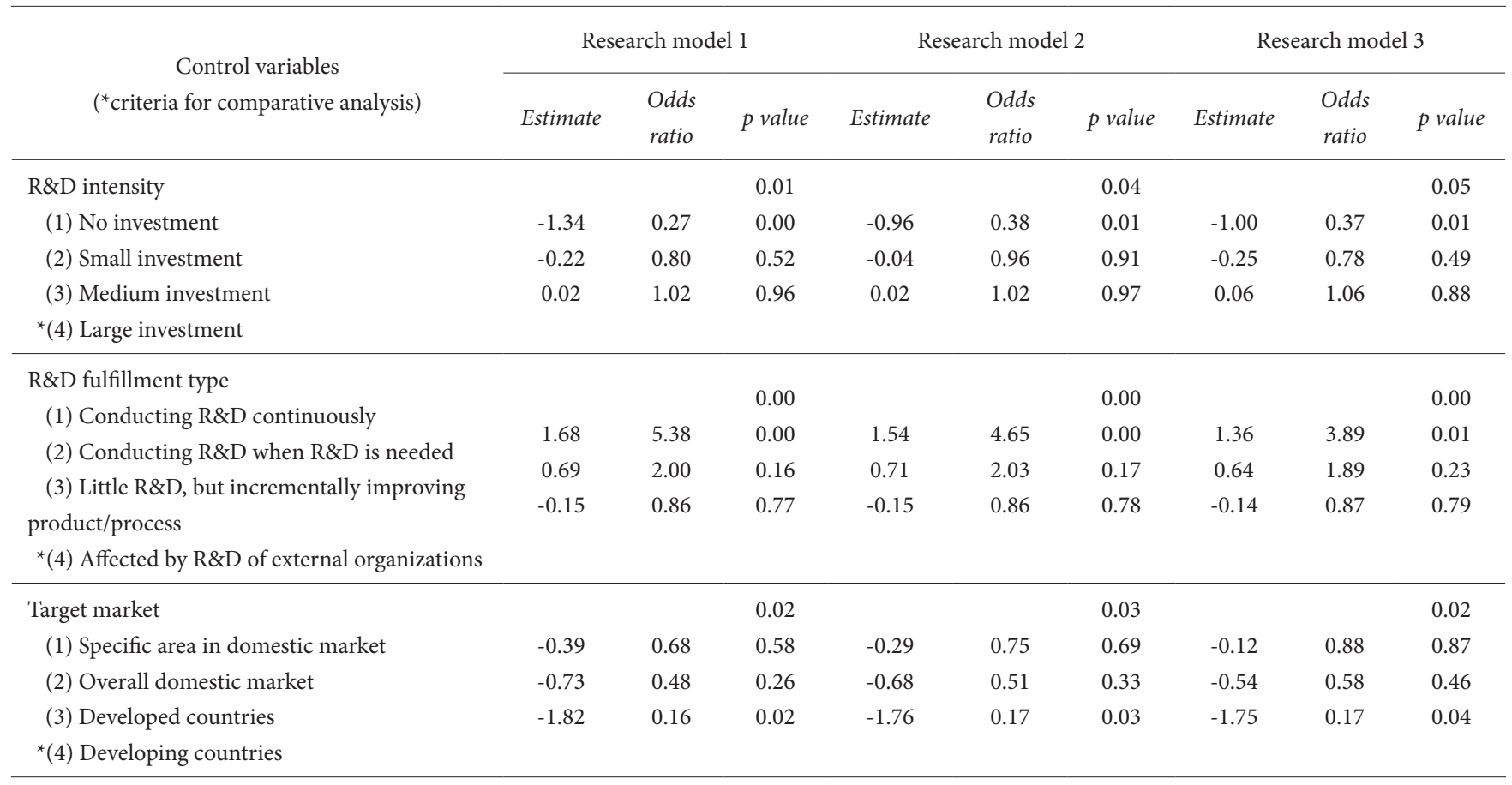

Table 6. In-depth analysis of the impact of control variables

Thirdly, statistically significant control variables should be identified in more detail, as the type of control variable is categorical. For this purpose, the categorical variables were recoded into dummy variables, and a logistic regression model was developed using the dummy variables except ones that were used as criteria for comparative analysis. Then, logistic analysis was conducted, and the detailed impact of categorical variables could be investigated, as shown in Table 6. The impact of each control variable is as follows: Regarding the impact of R\&D intensity on the collaboration tendency, it is clear that no R\&D investment reduces the propensity of collaboration in SMEs, though it is not always true that large investment in R\&D is associated with a high propensity to collaborate. SMEs with small R\&D investment may want to work with $\mathrm{R} \& \mathrm{D}$ organizations to compensate for weaknesses. SMEs with large R\&D investment may also want to collaborate with others to sell or license their R\&D outputs. For the impact of R\&D fulfillment type on the collaboration tendency, SMEs tend to conduct collaboration more actively when they conduct R\&D continuously. Combining with the implications from the previous variable-R\&D intensity-what is important to determine the collabo- ration propensity is not the amount of R\&D investment but the continuity of $\mathrm{R} \& \mathrm{D}$ activities. As to the target markets with respect to the collaboration tendency, SMEs are not likely to be involved in collaboration when their target market is developed countries. SMEs targeting developed countries have enough capabilities, and their need to collaborate may be relatively less vital than others'.

Fourthly, it is worth discussing the role of R\&D support services (e.g., R\&D services, market and technology trend analysis services, intellectual property management services) to boost innovation in SMEs. These are the services that can make up for the weak points of SMEs, as SMEs are lacking in management capabilities. In our analysis, it was shown that SMEs regard "internal strategies or external partners relating to R\&D” as quite important. At the same time, SMEs are commonly described as lacking internal resources, and this makes it hard for them to accomplish technological innovation alone. Therefore, collaborating with the R\&D support service firms may give great benefits to SMEs, increasing their innovation capabilities and further increasing the possibilities of success in collaboration with external partners.

\begin{tabular}{lccccc}
\hline \multicolumn{1}{c}{ Model } & AUC & $\begin{array}{c}\text { Difference } \\
\text { between AUC }\end{array}$ & S.E & Z statistic & p-value \\
\hline Research model 1 & 0.81 & & 0.02 & & \\
Research model 2 & 0.84 & & 0.02 & & \\
Research model 3 & 0.85 & & 0.02 & & \\
Research model 1 \& Research model 2 & & $0.03^{* *}$ & 0.01 & 2.72 & 0.01 \\
Research model 1 \& Research model 3 & & $0.04^{* *}$ & 0.01 & 3.14 & 0.00 \\
Research model 2 \& Research model 3 & & 0.01 & 0.01 & 0.87 & \\
\hline$* *$ p-value $<0.01$ & & & & &
\end{tabular}

Table 7. AUC calculation and pairwise comparison results 
Finally, we can also assess the influence of explanatory variables on predictors through ROC curve analysis. In this analysis, the influence of the factors can be compared by AUC. The results of this comparison, shown in Table 7, indicate that the internal collaboration mode is much more significant to describe the propensity of SMEs conducting external collaboration than the external collaboration partners. Although both the collaboration mode and the collaboration partner have a relative correlation and describe the propensity well, the collaboration mode can represent an actual behavior of SMEs much better. It might happen that a collaboration mode of an SME can be decided by the needs of the firm alone, while a collaboration partner cannot be selected by a firm's own needs.

\section{Conclusion}

This research investigated the perceptual factors affecting SMEs' external collaboration by using multidimensional data. It is one of earliest attempts to investigate perceptions about the collaboration strategies of SMEs, which is particularly significant in understanding the strategic behavior toward OI in SMEs. From the research findings, two implications were derived. First, managers or policymakers should understand the firm's internal attitude toward accepting outside knowledge or trusting cooperative partners before forcing external collaboration on them indiscriminately. Second, exploratory efforts to accumulate outside ideas or to become aware of outside demands can be a good initial step in exploring external collaboration. Amassing a large number of information sources may help to lay the groundwork for future collaborations, as SMEs have limited ability to access external information.

Despite these implications, three limitations also remain. First, this research is based on cross-sectional data. If there are unexpected or unconsidered events in the survey period, undefined problems may occur. Thus, a longitudinal approach is needed to address this problem. Second, only SMEs in three industrial sectors in Korea were included in this research. The national innovation system or ethnicity, culture, and laws of the SMEs all have the potential to distort the results. SMEs in other countries should be considered in future research to address the problem of generalization. Finally, further analysis needs to address not only the collaboration tendency but also collaboration success, In particular, business environmental power, especially R\&D support services, with both internal collaboration modes and external collaborative partners should be investigated for the collaboration success of SMEs. Because SMEs' problems engaging in collaboration success are much more complex than whether SMEs conduct collaboration or not with only internal strategies and external partners, and, therefore, other factors about the business environment are badly needed. Although the range of factors relating to business environment is very wide, a level of R\&D support service around SMEs can be meaningful.

\section{References}

Anand, BN., Khanna, T. (2000). The structure of licensing contracts, The Journal of Industrial Economics, 48(1), 103-135. http://dx.doi. org/10.1111/1467-6451.00114

Arora, A., Fosfuri, A. (2003). Licensing the market for technology, Journal of Economic Behavior \& Organization, 52(2), 277-295.

Athreye, S., Cantwell, J. (2007). Creating competition?: globalisation and the emergence of new technology producers, Research Policy, 36(2), 209-226. http://dx.doi.org/10.2139/ssrn.824005

Bianchi, M., Campodall'Orto, S., Frattini, F., Vercesi, P. (2010). Enabling open innovation in small-and medium-sized enterprises: how to find alternative applications for your technologies, $R \& D$ Management, 40(4), 414-431. http://dx.doi.org/10.1111/j.14679310.2010.00613.x

Bougrain, F., Haudeville, B. (2002). Innovation, collaboration and SMEs internal research capacities, Research Policy, 31(5), 735-747. http://dx.doi.org/10.1016/s0048-7333(01)00144-5

Chen, J., Chen, Y., Vanhaverbeke, W. (2011). The influence of scope, depth, and orientation of external technology sources on the innovative performance of Chinese firms, Technovation, 31(8), 362-373. http://dx.doi.org/10.1016/j.technovation.2011.03.002

Chesbrough, H. (2003). The logic of open innovation: managing intellectual property, California Management Review, 45(3), 33-58. http://dx.doi.org/10.2307/41166175.

Chesbrough, H. (2012). Open innovation: where we've been and where we're going, Research-Technology Management, 55(4), 20-27. http://dx.doi.org/10.5437/08956308x5504085

Chesbrough, H. (2003). Open Innovation: The New Imperative for Creating and Profiting from Technology, Harvard Business Press, Boston, MA.

Chesbrough, H., Vanhaverbeke, W., West, J. (2006). Open Innovation: Researching a New Paradigm, Oxford University Press, Oxford.

Chiaroni, D., Chiesa, V., Frattini, F. (2011). The open innovation journey: how firms dynamically implement the emerging innovation management paradigm, Technovation, 31(1), 34-43. http://dx.doi. org/10.1016/j.technovation.2009.08.007

Cho, C., Yoon, B., Coh, BY., Lee, S. (2015). An empirical analysis on purposes, drivers and activities of technology opportunity discovery: the case of Korean SMEs in the manufacturing sector (in press), RઐD Management. http://dx.doi.org/10.1111/radm.12107

DeLong, ER., DeLong, DM., Clarke-Pearson, DL. (1988). Comparing the areas under two or more correlated receiver operating characteristic curves: a nonparametric approach, Biometrics, 44(3), 837-845. http://dx.doi.org/10.2307/2531595 
Doloreux, D., Mattson, H. (2008). To what extent do sectors "Socialize" innovation differently? mapping cooperative linkages in knowledge-intensive industries in the Ottawa region, Industry and Innovation, 15(4), 351-370. http://dx.doi. org/10.1080/13662710802239463

Enkel, E., Gassmann, O., Chesbrough, H. (2009). Open R\&D and open innovation: exploring the phenomenon, R\&D Management, 39(4), 311-316. http://dx.doi.org/10.1111/j.1467-9310.2009.00570.x

Eriksson, M., Niitamo, VP., Kulkki, S. (2005). State-of-the-art in utilizing Living Labs approach to user-centric ICT innovation-a European approach, Lulea: Center for Distance-spanning Technology. Lulea University of Technology Sweden: Lulea

Fey, CF., Birkinshaw, J. (2005). External sources of knowledge, governance mode, and R\&D performance, Journal of Management, 31(4), 597-621. http://dx.doi.org/10.1177/0149206304272346

Fitjar, RD., Rodríguez-Pose, A. (2013). Firm collaboration and modes of innovation in Norway, Research Policy, 42(1), 128-138. http://dx. doi.org/10.1016/j.respol.2012.05.009

Gassmann, O. (2006). Opening up the innovation process: towards an agenda. R\&D Management, 36(3), 223-228. http://dx.doi. org/10.1111/j.1467-9310.2006.00437.x

Hageddom, J. (2002). Inter-firm R\&D partnerships: an overview of major trends and patterns since 1960, Research Policy, 31(4), 477-492. http://dx.doi.org/10.1016/s0048-7333(01)00120-2

Hamdani, J., Wirawan, C. (2012). Open innovation implementation to sustain Indonesian SMEs, Procedia Economics and Finance, 4, 223 233. http://dx.doi.org/10.1016/s2212-5671(12)00337-1

Harrison, RT., Hart, M. (1987). Innovation and market development: the experience of small firms in a peripheral economy, Omega, 15(6), 445-454. http://dx.doi.org/10.1016/0305-0483(87)90002-8

Hollanders, H., Esser, FC. (2007). Measuring innovation efficiency, INNO-Metrics Thematic Paper.

Hung, KP., Chou, C. (2013). The impact of open innovation on firm performance: the moderating effects of internal R\&D and environmental turbulence, Technovation, 33(10), 368-380. http://dx.doi. org/10.1016/j.technovation.2013.06.006

Husted, BW., Allen, DB. (2007). Corporate social strategy in multinational enterprises: Antecedents and value creation, Journal of Business Ethics, 74(4), 345-361. http://dx.doi.org/10.1007/s10551-007-9511-4

Kafouros, MI., Forsans, N. (2012). The role of open innovation in emerging economies: do companies profit from the scientific knowledge of others?, Journal of World Business, 47(3), 362-370. http://dx. doi.org/10.1016/j.jwb.2011.05.004
Kamalian, A., Rashki, M., Arbabi, ML. (2011). Barriers to Innovation among Iranian SMEs, Asian Journal of Business Management, 3(2), 79-90.

Kang, KN., Park, H. (2012). Influence of government R\&D support and inter-firm collaborations on innovation in Korean biotechnology SMEs, Technovation, 32(1), 68-78. http://dx.doi.org/10.1016/j.technovation.2011.08.004

Kani, M., Motohashi, K. (2012) Understanding the technology market for patents: new insights from a licensing survey of Japanese firms, $R$ esearch P olicy, 21(1), 226-235. http://dx.doi.org/10.1016/j. respol.2011.08.002

Keupp, MM., Gassmann, O. (2009). Determinants and archetype users of open innovation, R\&D Management, 39(4), 331-341. http:// dx.doi.org/10.1111/j.1467-9310.2009.00563.x

Kurokawa, S. (1997). Make-or-buy decisions in R\&D: small technology based firms in the United States and Japan, IEEE Transactions on Engineering Management, 44(2), 124-134. http://dx.doi. org/10.1109/17.584921

Laursen, K., Salter, A. (2006). Open for innovation: the role of openness in explaining innovation performance among UK manufacturing firms, Strategic Management Journal, 27(2), 131-150. h ttp://dx. doi.org/10.1002/smj.507

Lee, S., Park, G., Yoon, B., Park, J. (2010). Open innovation in SMEsan intermediated network model, Research Policy, 39(2), 290-300. http://dx.doi.org/10.1016/j.respol.2009.12.009

Lee, Y., Shin, J., Park, Y. (2012). The changing pattern of SME's innovativeness through business model globalization, Technological Forecasting and Social Change, 79(5), 832-842. http://dx.doi.org/10.1016/j. techfore.2011.10.008

Levy, M., Powell, P. (1998). SME flexibility and the role of information systems, Small Business Economics, 11(2), 183-196.

Lipparini, A., Sobrero, M. (1994). The glue and the pieces: entrepreneurship and innovation in small-firm n etworks, $J$ ournal o $f$ Business Venturing, 9(2), 125-140. http://dx.doi.org/10.1016/08839026(94)90005-1

Lu, JW., Beamish, PW. (2001). The internationalization and performance of SMEs, Strategic Management Journal, 22, 565-586. http:// dx.doi.org/10.1002/smj.184.abs

Mendi, P. (2007). Trade in disembodied technology and total factor productivity in OECD countries, Research Policy, 36(2), 209-226. http://dx.doi.org/10.1016/j.respol.2006.09.028

Mortara, L., Minshall, T. (2011). How do large multinational companies implement open innovation?, Technovation, 31(10), 586-597. http://dx.doi.org/10.1016/j.technovation.2011.05.002 
Mosakowski, E. (1993). A resource-based perspective on the dynamic strategy-performance relationship: an empirical examination of the focus and differentiation strategies in, Journal of Management, 19(4), 819-839. http://dx.doi.org/10.1016/0149-2063(93)90029-m

Narula, R. (2004). R\&D collaboration by SMEs: new opportunities and limitations in the face of globalization, Technovation, 24(2), 153161. http://dx.doi.org/10.1016/s0166-4972(02)00045-7

OECD. (2011). 2010 OECD Annual Report, OECD.

Parida, V., Westerberg, M., Frishammar, J. (2012). Inbound open innovation activities in high-tech SMEs: the impact on innovation performance, Journal of Small Business Management, 50(2), 283-309. http://dx.doi.org/10.1111/j.1540-627x.2012.00354.x

Parmentier, G., Mangematin, V. (2014). Orchestrating innovation with user communities in the creative industries, Technological Forecasting and Social Change, 83, 40-53. http://dx.doi.org/10.1016/j.techfore.2013.03.007

Pavitt, K. (1983). Characteristics of innovative activities in British industry, Omega, 11(2), 113-130. http://dx.doi.org/10.1016/03050483(83)90001-4

Roathwell, R. (1984). The role of small firms in the emergence of new technologies, Omega, 12(1), 19-29. http://dx.doi.org/10.1016/03050483(84)90007-0

Robson, PJ., Bennett, RJ. (2000). SME growth: the relationship with business advice and external collaboration, Small Business Economics, 15(3), 193-208.

Rosenfeld, S. A. (1996). Does cooperation enhance competitiveness? Assessing the impacts of inter-firm collaboration. Research policy, 25(2), 247-263. http://dx.doi.org/10.1016/0048-7333(95)00835-7

Savitskaya, I., Salmi, P., Torkkeli, M. (2010). Barriers to open innovation: case China, Journal of Technology Management \& Innovation, 5(4), 10-21. http://dx.doi.org/10.4067/s0718-27242010000400002

Sisodiya, SR., Johnson, JL., Grêgoire, Y. (2013). Inbound open innovation for enhanced performance: enablers and opportunities, Industrial Marketing Management, 42(6), 836-849. http://dx.doi. org/10.1016/j.indmarman.2013.02.018

Statistics Korea. (2013). SME Export Status Index.
Sudhir kumar, R., Bala Subrahmanya., MH. (2010). Influence of subcontracting on innovation and economic performance of SMEs in Indian automobile industry, Technovation, 30(11), 558-569. http:// dx.doi.org/10.1016/j.technovation.2010.06.005

Thong, JY. (2001). Resource constraints and information systems implementation in Singaporean small businesses, Omega, 29(2), 143156. http://dx.doi.org/10.1016/s0305-0483(00)00035-9

Tidd, J., Bessant, J., Pavitt, K. (2005). Managing Innovation: Integrating Technology, Market and Organizational Change 3rd edition, John Wiley \& Sons, Chichester.

Tomlinson, PR., Fai, FM. (2013). The nature of SME co-operation and innovation: a multi-scalar and multi-dimensional analysis, International Journal of Production Economics, 141(1), 316-326. http:// dx.doi.org/10.1016/j.ijpe.2012.08.012

Van de Vrande, V., De Jong, JP., Vanhaverbeke, W., De Rochemont., M. (2009). Open innovation in SMEs: trends, motives and management challenges, Technovation, 29(6), 423-437. http://dx.doi.org/10.1016/j. technovation.2008.10.001

Wadhwa, RS. (2012). Flexibility in manufacturing automation: a living lab case study of Norwegian metalcasting SMEs, Journal of Manufacturing Systems, 31(4), 444-454. http://dx.doi.org/10.1016/j. jmsy.2012.07.008

West, J., Gallagher., S. (2006). Challenges of open innovation: the paradox of firm investment in open-source software, RઐD Management, 36(3), 319-331. http://dx.doi.org/10.1111/j.1467-9310.2006.00436.x

Westhead, P., Storey, DJ. (1995). Links between higher education institutions and high technology firms, Omega, 23(4), 345-360. http:// dx.doi.org/10.1016/0305-0483(95)00021-f

Wren, C., Storey, DJ. (2002). Evaluating the effect of soft business support upon small firm performance, Oxford Economic Papers, 54(2), 334-365. http://dx.doi.org/10.1093/oep/54.2.334

Wyatt, S. (1982). The Role of Small Firms in Innovative Activity: Some New Evidence, Mimeo, SPRU, Sussex.

Xu, T., Bower, D. A., \& Smith, N. J. (2005). Types of collaboration between foreign contractors and their Chinese partners. International Journal of Project Management, 23(1), 45-53. http://dx.doi. org/10.1016/j.ijproman.2004.05.012 